Journal of Applied Pharmaceutical Science Vol. 6 (05), pp. 193-197, May, 2016

Available online at http://www.japsonline.com

DOI: 10.7324/JAPS.2016.60530

ISSN 2231-3354 (cc) BY-NC-SA

\title{
Anti-inflammatory and Neuropharmacological activities of the seed extract of Setaria italica
}

\author{
Tumpa Dasgupta*, Saikat Kumar Poddar, Amlan Ganguly, Nazmul Qais \\ Department of Clinical Pharmacy and Pharmacology, Faculty of Pharmacy, University of Dhaka, Dhaka-1000, Bangladesh.
}

\begin{tabular}{|c|c|}
\hline ARTICLE INFO & ABSTRACT \\
\hline $\begin{array}{l}\text { Article history: } \\
\text { Received on: } 24 / 02 / 2016 \\
\text { Revised on: } 17 / 03 / 2016 \\
\text { Accepted on: } 18 / 04 / 2016 \\
\text { Available online: } 28 / 05 / 2016\end{array}$ & $\begin{array}{l}\text { Setaria italica (Poaceae) has been used in folk medicine to treat inflammation, pain, arthralgia and many } \\
\text { neurological disorders. The objective of the study is screening of ethanolic extract of Setaria italica seeds for } \\
\text { possible anti-inflammatory and neuropharmacological activities in rats and mice respectively. Anti- } \\
\text { inflammatory activity was evaluated by carrageenan induced paw edema inhibition method while the } \\
\text { neuropharmacological potential was evaluated by three separate methods: Hole-cross test, Open-field method }\end{array}$ \\
\hline $\begin{array}{l}\text { Key words: } \\
\text { Setaria italica, Poaceae, } \\
\text { Anti-inflammatory, Open- } \\
\text { field, Hole-cross, CNS- } \\
\text { depressant. }\end{array}$ & $\begin{array}{l}\mathrm{mg} / \mathrm{kg} \text { body weight showed a strong anti-inflammatory activity with } 20.16,65.44,65.5 \text { and } 71.15 \% \text { inhibition of } \\
\text { paw edema respectively after } 1^{\text {st }}, 2^{\text {nd }}, 3^{\text {rd }} \text { and } 4^{\text {th }} \text { hrs of carrageenan injection which is comparable to that of } \\
\text { standard drug diclofenac sodium at } 100 \mathrm{mg} / \mathrm{kg} \text { body weight }\left(\% \text { inhibition } 92.3 \% \text { at } 4^{\text {th }} \text { hour } * * P<0.001\right) \text {. In } \\
\text { Hole-cross test, ethanolic extracts of Setaria italica at } 400 \mathrm{mg} / \mathrm{kg} \text { body weight dose have prominent CNS } \\
\text { depressant activity which is comparable to standard Diazepam. In open field test, S. italica at } 400 \mathrm{mg} / \mathrm{kg} \text { body } \\
\text { weight significantly suppressed the movements which is comparable to standard Diazepam. In Phenobarbitone } \\
\text { induced test, Setaria italica did not show any significant CNS-depressant activity. The findings of the studies } \\
\text { demonstrate anti-inflammatory and neuropharmacological properties of Setaria italica which could be } \\
\text { therapeutic option against inflammation and neurological disorders. }\end{array}$ \\
\hline
\end{tabular}

\section{INTRODUCTION}

In spite of the great advancements observed in modern medicines in recent decades, plants still make an important contribution to health care (Calixto et al., 2000). Over the past decades, interest in drugs derived from higher plants, especially the phytotherapeutic ones, has increased expressively (Calixto, 2000). Setaria italica (foxtail millet) also known as kaoun, kakun belongs to the family Poaceae. It is traditionally used for its antiinflammatory activity (Ghani, 2003) and now-a-days praised as a grain with low glycemic index (Bala, 2004). Setaria italica was

* Corresponding Author

Tumpa Dasgupta, Department of Clinical Pharmacy and Pharmacology, Faculty of Pharmacy, University of Dhaka, Dhaka-1000, Bangladesh. Email:dasgupta@du.ac.bd domesticated from the wild Setaria viridis in East Asia more than 7000 years ago (Hitchcock, 1950). Foxtail millet is nowadays a minor crop in SE Europe, parts of Asia (especially India, China, Bangladesh and Japan) and North Africa (Hafliger and Scholz, 1981). The seeds part of Setaria italica has been traditionally used by rural people to treat inflammation. The goal of our study was to evaluate the extent of the anti-inflammatory potential of Bangladeshi species of Setaria italica. Along with the antiinflammatory activity, an effort was done to investigate whether the plant has any neuropharmacological property. So, in the present study, anti-inflammatory activity was determined by carragennan-induced rat hind paw edema inhibition method and neuropharmacological potential was evaluated by three distinct methods: Hole-cross test, Open-field method and Phenobarbitone induced sleeping time test. 


\section{MATERIALS AND METHODS}

\section{Collection and Preparation of Plant Material}

Fresh seeds of Setaria italica was collected from Kurigram, Bangladesh, in October, 2011. Then exact identification of plant sample was done by an expert taxonomist. After sundrying of the seeds for several days, these were then oven dried for 24 hours at considerably low temperature for better grinding. The dried seeds were then ground into coarse powder in the Phytochemical Research Laboratory, Faculty of Pharmacy, University of Dhaka.

\section{Extraction of the Plant Material}

About $850 \mathrm{gm}$ of the powdered material was soaked in 3.5 liter of ethanol. The container was sealed and kept for a period of 15 days accompanying occasional shaking and stirring. The whole mixture was then filtered and the filtrate thus obtained was concentrated at $39^{\circ} \mathrm{C}$ with a Heidolph rotary evaporator. The concentrated extract was air dried to solid residue. The weight of the crude ethanol extract obtained from the powdered seeds was 20 gm.

\section{Drugs and Chemicals}

All chemicals used were of analytical reagent grade. Ethanol and Acetic acid were obtained from Merck Germany. The drugs Diclofenac sodium, Diazepam, Phenobarbitone were obtained from Square Pharmaceuticals Ltd., Bangladesh. Dimethyl Sulphoxide (DMSO) was procured from India. Saline and distilled water were collected from University instruments Lab.

\section{Experimental animal}

Swiss albino mice of either sex weighing 25-30 $\mathrm{g}$ were obtained from the animal house of the International Centre for Diarrheal Disease and Research, Bangladesh (ICDDR'B). The animals were housed under standard laboratory conditions (relative humidity $55-65 \%$, room temperature $23.0 \pm 2.0^{\circ} \mathrm{C}$ and 12 h light: dark cycle). The animals were fed with standard diet and water ad libitum. The design and the performance of research study involving mice and rats have been approved by the Ethical Review Committee, Faculty of Biological Science, University of Dhaka, through the submission of a research protocol (FBS/DU/09/2011) before the study.

\section{Phytochemical screening}

The freshly prepared crude ethanolic extracts of Setaria italica seeds were qualitatively tested for the presence of flavonoids, alkaloids, terpenoids, triterpenoids, tannins, phenolics, and reducing sugar by using standard phytochemical procedures (Ghani, 2003; Trease \& Evans, 1989).

\section{Anti-inflammatory activity}

In this experiment, carragennan-induced rat hind paw edema was used as the animal model of acute inflammation according to Winter 1962 (Lamba et al., 2000). Administration of carrageenan in the sub-plantar region of rat's hind paw leads to the formation of edema in situ due to localized inflammation. About one hour prior to the administration of carrrageenan solution, experimental animals received test materials and standard antiinflammatory drug at appropriate doses. The volume of rat's paw was measured each hour up to five hours by plethysmometer (Ugo Basile, Italy). The average percentage of increase in paw volume with time was calculated and compared against the control group. Percent inhibition was calculated using the formula-

$$
\% \text { inhibition }=\frac{\mathrm{Vc}-\mathrm{Vt}}{\mathrm{Vc}} \times 100
$$

Where, $V_{c}$ and $V_{t}$ represent the average edema volume of control and treated animals respectively. Diclofenac sodium $100 \mathrm{mg} / \mathrm{kg}$ body weight was used as standard anti-inflammatory agent.

\section{Neuropharmacological activity \\ Hole cross test}

The method was carried out as described by Takagi. (Takagi et al., 1972). A steel partition was fixed in the middle of a cage having a size of $30 \times 20 \times 14 \mathrm{~cm}$. A hole of $3 \mathrm{~cm}$ diameter was made at a height of $7.5 \mathrm{~cm}$ in the center of the cage. The animals were divided into control, positive control and test groups containing five mice each. The test groups received extract of Setaria italica at the doses of $400 \mathrm{mg} / \mathrm{kg}, 200 \mathrm{mg} / \mathrm{kg}$ and 100 $\mathrm{mg} / \mathrm{kg}$ body weight orally whereas the vehicle control and positive control groups received vehicle (DMSO) and the standard drug diazepam (1 $\mathrm{mg} / \mathrm{kg}$ body weight) respectively. The number of passage of a mouse through the hole from one chamber to other was counted for a period at $0,30,60,90$ and $120 \mathrm{~min}$ after oral administration of the test drugs and the standard.

\section{Open field test}

The Open Field Test (OFT) is clearly the most frequently used of all behavioural tests in pharmacology and neuroscience. Open-field behavioral assays are commonly used to test both locomotor activity and emotionality in rodents. In open field test, the animals were divided into control, positive control, and test groups containing five mice each. The test groups received ethanolic extract of Setaria italica at the doses of $400 \mathrm{mg} / \mathrm{kg}$ body weight orally whereas the control group received vehicle distilled water. Animals in positive control group received diazepam (1 $\mathrm{mg} / \mathrm{kg}$ body weight). The floor of an open field of half square meter was divided into a series of squares each alternatively colored black and white. The number of squares visited by the animals was counted at 0, 30, 60, 90, and $120 \mathrm{~min}$ after oral administration of the test drugs and the standard (Gupta et al., 1971).

\section{CNS-depressant Activity}

Evaluation of CNS-depressant activity was done by phenobarbitone induced sleeping time test. Fifteen experimental animals were randomly selected and divided into three groups denoted as group-I, group- II and group- III consisting of 5 mice in each group. Each group received a particular treatment. 


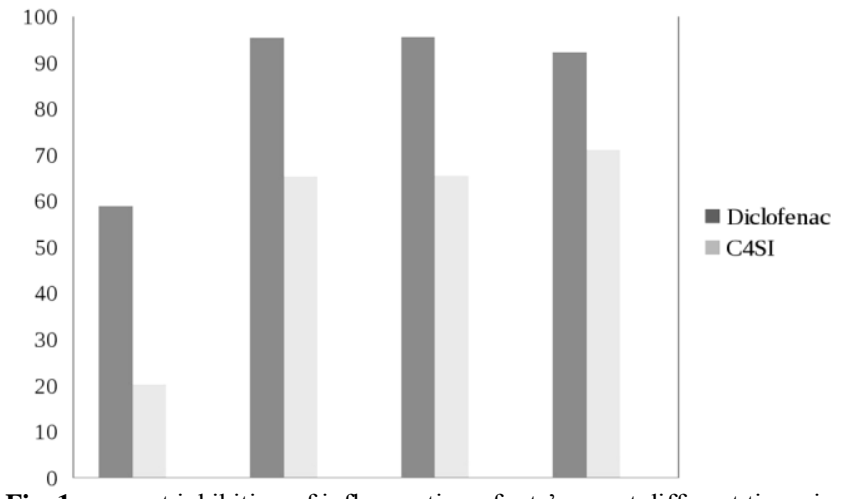

Fig. 1: percent inhibition of inflammation of rats' paw at different times in different groups.

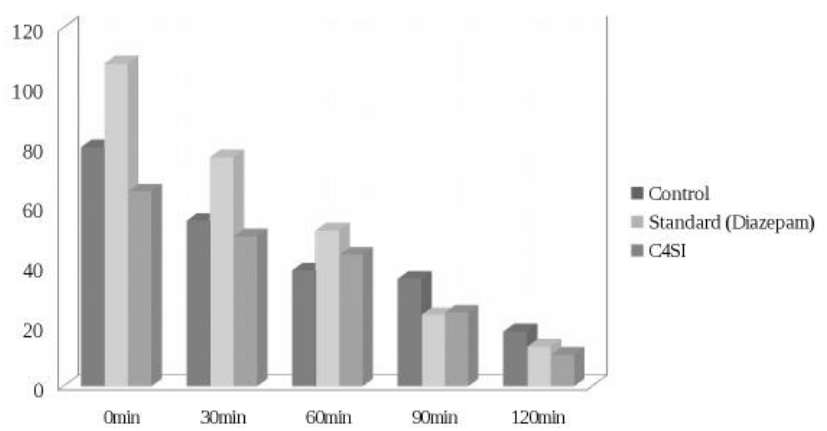

Fig. 3: difference in number of movements of mice in different groups in open field test.

Prior to any treatment, each mouse was weighed properly and the doses of the test samples and control materials were adjusted accordingly. The animals were individualized and marked as M-1= Mice 1, M-2= Mice 2, M-3= Mice 3, M-4= Mice 4 and M-5= Mice 5. In this method the test group received the ethanolic crude extracts and the control group received vehicle (1\% tween 80 in normal saline). Thirty minutes later, phenobarbitone (40 $\mathrm{mg} / \mathrm{kg}$, intra-peritoneal) was administered to each mouse to induce sleep.

The animals were observed for the latent period (time between phenobarbitone administration to loss of righting reflex) and duration of sleep (time between the loss and recovery of righting reflex). (Yu et al., 2002)

\section{Statistical analysis}

All values were expressed as the mean \pm standard error of the mean (SEM) and the results were analysed statistically by one-way analysis of variance (ANOVA) followed by Dunnett's ttest by using SPSS ver.16 (SPSS Inc., Chicago, IL). p $<0.05$ was considered to be statistically significant.

\section{RESULT AND DISCUSSION}

\section{Phytochemical Screening}

Preliminary phytochemical screening of ethanolic extracts of the seeds of Setaria italica revealed the presence

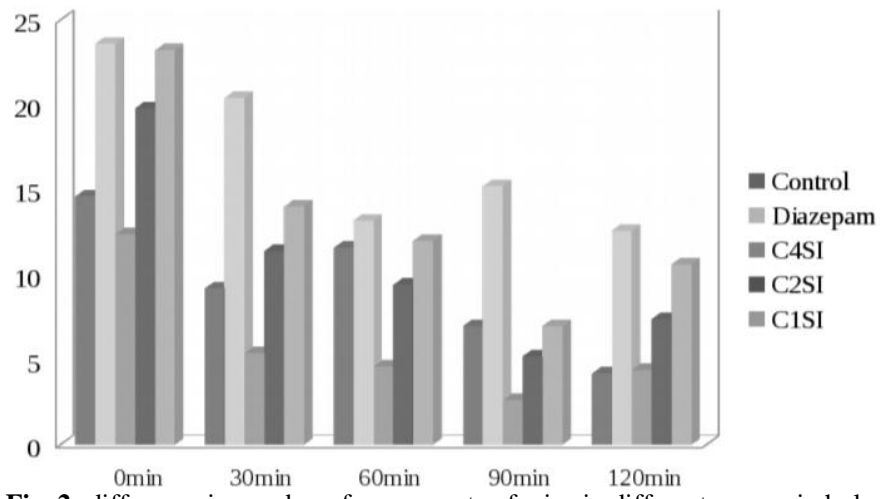

Fig. 2: difference in number of movements of mice in different groups in hole cross test.

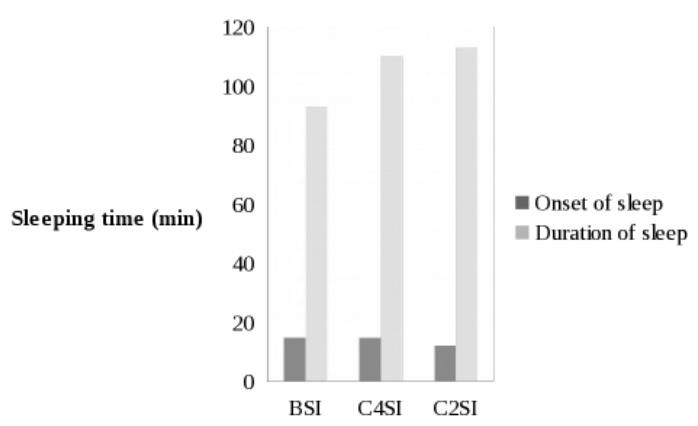

Fig. 4: plot of onset and duration of sleeping time in min

of various bioactive compounds like flavonoids, alkaloids, terpenoids, triterpenoids, tannins, phenolics and reducing sugar (Table 1).

Table 1: Results of different chemical group tests of the ethanolic extract of $S$. italica seeds.

\begin{tabular}{|c|c|c|c|c|c|c|c|}
\hline 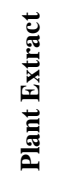 & 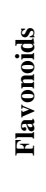 & 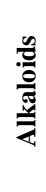 & 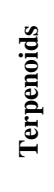 & 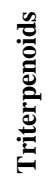 & 兑 & $\frac{\mathscr{n}}{\frac{\mathscr{n}}{0}}$ & 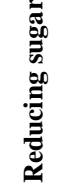 \\
\hline CSI & + & + & + & + & + & + & + \\
\hline
\end{tabular}

\section{Anti-inflammatory activity}

In the carrageenan induced rat paw edema inhibition test for acute inflammation, the crude ethanolic extract of seeds of Setaria italica at $400 \mathrm{mg} / \mathrm{kg}$ body weight showed a strong antiinflammatory activity with $20.16,65.44,65.5$ and $71.15 \%$ inhibition of paw edema respectively after $1^{\text {st }}, 2^{\text {nd }}, 3^{\text {rd }}$ and $4^{\text {th }}$ hours of carrageenan injection (Table 2). The anti-inflammatory potential was increased with time and reached the peak level at the $4^{\text {th }}$ hour of the study which is comparable to that of standard drug diclofenac sodium at $100 \mathrm{mg} / \mathrm{kg}$ body weight (\% inhibition $92.3 \%$ 
at $4^{\text {th }}$ hour $\left.* * \mathrm{P}<0.001\right)$. These results are found to be statistically significant $(* \mathrm{P}<0.05)$ (Table-3) (Fig. 1). From this assay, it can be predicted that different extractives of Setaria italica may possess considerable anti-inflammatory potency. Chemical investigation and isolation of bioactive principles should be taken to establish the anti-inflammatory potential of the plant.

Table 2: Paw volume of rats receiving crude extracts of seeds of Setaria italica

\begin{tabular}{ccccc}
\hline & \multicolumn{4}{c}{ Paw volume $(\mathbf{m L})(\mathbf{m e a n} \pm$ SEM) } \\
\cline { 2 - 5 } Code & $\mathbf{1}^{\text {st }} \mathbf{h r}$ & $\mathbf{2}^{\text {nd }} \mathbf{h r}$ & $\mathbf{3}^{\text {rd }} \mathbf{h r}$ & $\mathbf{4}^{\text {th }} \mathbf{h r}$ \\
\hline Control & $1.012 \pm 0.09$ & $1.046 \pm 0.1$ & $1.006 \pm 0.09$ & $0.982 \pm 0.07$ \\
Diclofenac & $0.776 \pm 0.01^{*}$ & $0.69 \pm 0.03^{* * *}$ & $0.688 \pm 0.03^{* * *}$ & $0.694 \pm 0.03^{* *}$ \\
C4SI & $0.97 \pm 0.02$ & $0.874 \pm 0.04$ & $0.86 \pm 0.02$ & $0.84 \pm 0.04$ \\
\hline
\end{tabular}

Values are mean \pm SEM $(\mathrm{n}=5) ; * * * \mathrm{P}<0.001, * * \mathrm{P}<0.01, * \mathrm{P}<0.05$ compared to control. C4SI $=$ crude ethanolic extract $(400 \mathrm{mg} / \mathrm{kg}$ body weight $)$

Table 3: Effect of ethanolic extract of Setaria italica seeds on carragennan induced rat paw edema

\begin{tabular}{|c|c|c|c|c|c|c|c|c|}
\hline \multirow[t]{2}{*}{ Group } & \multicolumn{5}{|c|}{$\begin{array}{c}\text { Paw edema (ml) } \\
(\mathrm{Ct}-\mathrm{Co})\end{array}$} & \multicolumn{3}{|c|}{$\begin{array}{c}\text { \% paw edema } \\
\text { inhibition }\end{array}$} \\
\hline & $1^{\text {st }} \mathrm{hr}$ & $2^{\text {nd }} \mathrm{hr}$ & $3^{\text {rd }} \mathrm{hr}$ & $4^{\text {th }} \mathrm{hr}$ & $1^{\text {st }} \mathrm{hr}$ & $2^{\text {nd }} \mathrm{hr}$ & $3^{\text {rd }} \mathrm{hr}$ & $4^{\text {th }} \mathrm{hr}$ \\
\hline Control & 0.238 & 0.272 & 0.232 & 0.208 & - & - & - & - \\
\hline Diclofenac & 0.098 & 0.012 & 0.01 & 0.016 & 58.82 & 95.5 & 95.6 & 92.30 \\
\hline C4SI & 0.19 & 0.094 & 0.08 & 0.06 & 20.16 & 65.44 & 65.5 & 71.15 \\
\hline
\end{tabular}

\section{Neuropharmacological activity}

\section{Hole cross test}

An important step in evaluating drug acting on CNS is to observe its effect on locomotor activity of the animal. The activity is a measurement of the level of excitability of the CNS (Mansur et al., 1980) and this decrease may be closely related to sedation resulting from depression of the central nervous system
(Ozturk et al., 1996). Again, from various researches, it was discovered that various bioactive compounds like flavonoids, alkaloids, terpenoids have tranquilizing and sedative activity. (Kuponiyi, 2013) The extracts decreased the locomotor activity as shown by the results of the hole cross test. From the results this is observed that, ethanolic extracts of seeds of Setaria italica at 400 $\mathrm{mg} / \mathrm{kg}$ body weight dose have prominent CNS depressant activity in hole cross test, which is comparable to the reference drug Diazepam at a dose of $1 \mathrm{mg} / \mathrm{kg}$ body weight (Table-4) (Fig. 2).

\section{Open field test}

In the open field test, the seeds parts of ethanolic extracts of $S$. italica at dose level of $400 \mathrm{mg} / \mathrm{kg}$ body weight significantly suppressed the movements from its initial score which is comparable to the reference drug Diazepam (Table5) (Fig. 3). The maximum suppression was exhibited at 90 and 120 min after drug administration.

\section{CNS-depressant Activity}

From the above CNS-depressant activity testing by phenobarbitone induced sleeping time test it has been observed that the ethanolic crude extract of seeds of Setaria italica at a dose of $200 \mathrm{mg} / \mathrm{kg}$ body weight and $400 \mathrm{mg} / \mathrm{kg}$ body weight did not show any significant ( $>0.05$ and $p>0.01$, respectively) CNSdepressant activity. But the crude extract may possess some hypnotic activity in comparison with the control, which is evident from the decrease in onset of sleep and increase in duration of sleep (Table-6) (Fig. 4)." Further study on this plant may give rise some chemically and pharmacologically active compounds of interest.

Table 4: Effect of ethanolic extract of Setaria italica in Hole cross test on mice.

\begin{tabular}{|c|c|c|c|c|c|c|}
\hline \multirow{2}{*}{ Group } & \multirow{2}{*}{ Dose (mg/kg) } & \multicolumn{5}{|c|}{ Number of movements } \\
\hline & & Omin & 30min & $60 \mathrm{~min}$ & 90min & $120 \mathrm{~min}$ \\
\hline Control & $0.1 \mathrm{ml} / \mathrm{mouse}$ & $14.6 \pm 1.82$ & $9.2 \pm 0.52$ & $11.6 \pm 1.19$ & $7 \pm 1.17$ & $4.2 \pm 0.87$ \\
\hline Diazepam & 1 & $23.6 \pm 2.17 *$ & $20.4 \pm 1.91 * * *$ & $13.2 \pm 1.78$ & $15.2 \pm 2.05^{* *}$ & $12.6 \pm 2.18 * *$ \\
\hline C4SI & 400 & $12.4 \pm 0.92$ & $5.4 \pm 0.36 * * *$ & $4.6 \pm 1.28 * *$ & $2.6 \pm 1.08 *$ & $4.4 \pm 0.87$ \\
\hline C2SI & 200 & $19.8 \pm 1.48$ & $11.4 \pm 0.61^{*}$ & $9.4 \pm 1.80$ & $5.2 \pm 1.56$ & $7.4 \pm 1.08 *$ \\
\hline C1SI & 100 & $23.2 \pm 1.43 * *$ & $14 \pm 0.63 * * *$ & $12 \pm 1.90$ & $7 \pm 1.52$ & $10.6 \pm 1.19 * *$ \\
\hline
\end{tabular}

Values are presented as mean \pm SEM, where $\mathrm{n}=5$. $* * * \mathrm{P}<0.001, * * \mathrm{P}<0.01, * \mathrm{P}<0.05$ compared to control.

Table 5: Effect of ethanolic extract of Setaria italica in Open field test on mice.

\begin{tabular}{|c|c|c|c|c|c|c|}
\hline \multirow{2}{*}{ Group } & \multirow{2}{*}{ Dose(mg/kg) } & \multicolumn{5}{|c|}{ Number of movements } \\
\hline & & $0 \mathrm{~min}$ & $30 \mathrm{~min}$ & $60 \mathrm{~min}$ & $90 \mathrm{~min}$ & $120 \mathrm{~min}$ \\
\hline Control & $0.1 \mathrm{ml} / \mathrm{mouse}$ & $80 \pm 6.12$ & $55.4 \pm 6.27$ & $38.8 \pm 3.82$ & $36 \pm 8.24$ & $18.2 \pm 4.97$ \\
\hline Diazepam & 1 & $108 \pm 2.61 * *$ & $76.6 \pm 2.60 *$ & $52.2 \pm 6.01$ & $23.8 \pm 4.85$ & $13.2 \pm 6.06$ \\
\hline C4SI & 400 & $65.2 \pm 14.14$ & $50.2 \pm 3.38$ & $44 \pm 3.52$ & $24.6 \pm 5.10$ & $10.4 \pm 1.91$ \\
\hline
\end{tabular}

Table 6: Effect of control and ethanolic extract of Setaria italica on phenobarbitone induced sleeping time.

\begin{tabular}{|c|c|c|c|}
\hline Group & Dose (mg/kg) & Onset of sleep (min) & Duration of sleep (min) \\
\hline Control (BSI) & $0.1 \mathrm{ml} / \mathrm{mouse}$ & $14.8 \min \pm 2.68^{*}$ & $93.0 \min \pm 6.97 *$ \\
\hline Test group (C4SI) & 400 & $14.6 \min \pm 2.77^{*}$ & $110.0 \mathrm{~min} \pm 10.21 * *$ \\
\hline Test group (C2SI) & 200 & $12.0 \min \pm 2.41 *$ & $113.0 \mathrm{~min} \pm 12.01 * *$ \\
\hline
\end{tabular}




\section{CONCLUSION}

It is clearly evident from the above findings that the seed extract of Setaria italica has significant anti-inflammatory and neuropharmacological properties. Our findings also justify some of the traditional uses of the plant species. Therefore, the plant is a good candidate for further chemical investigation to isolate the active constituents and screen some pharmacological potential on higher animal models.

\section{ACKNOWLEDGEMENTS}

The authors wish to express gratitude to the authority of animal house of International Centre for Diarrheal Disease and Research, Bangladesh (ICDDR, B), for providing experimental animals. The authors also acknowledge the help of Professor Dr. Sk. Nazrul Islam, Institute of Nutrition and Food Science, University of Dhaka, for giving the opportunity to use their animal house during the study. The authors are also grateful to the authority of Department of Clinical Pharmacy \& Pharmacology, Faculty of Pharmacy, University of Dhaka for providing laboratory facilities.

\section{REFERENCES}

Bala RS. Neglected millets that save the poor from starvation. LEISA Ind, 2004; 6 (1):34-36.

Calixto JB, Beirith A, Ferreira J, Santos AR, Cechinel FV, Yunes RA. Naturally occurring anti-nociceptive substances from plants. Phytother. Res, 2000; 14:401-418.

Calixto, JB. Efficacy, safety, quality control, marketing and regulatory guidelines for herbal medicines (phytotherapeutic agents). Braz. J. Med. Biol. Res, 2000; 33:179- 189.
Ghani A. 2003. Medicinal plants of Bangladesh with chemical constituents and uses. Dhaka, Bangladesh: Asiatic Society of Bangladesh.

Gupta BD, Dandiya PC, Gupta ML. A psychopharmacological analysis of behavior in rat. The Japanese J Pharmacol, 1971; 21:293.

Hafliger E, Scholz H. 1981. Grass Weeds: Weeds of the subfamilies Chloridoideae, Pooideae, and Oryzoideae. Basle, Switzerland: CIBA-GEIGY Ltd.

Hitchcock AS. 1950. Manual of the Grasses of the United States. New York, USA: Dover Publications.

Kuponiyi TIE. Plant-Derived Compounds with Potential Sedative and Anxiolytic Activities. Int J of Basic and Applied Sci, 2013; 1:63-78.

Lamba SS, Buch KY, Lewis H, Lamba HJ. Phytochemicals as potential hypoglycemic agents. Studies in Nat Products Chemistry, 2000; 21:457-495.

Mansur RM, Martz W, Carlini, E.A. Effects of acute and chronic administration of Cannabis satis and (-) 9-trans tetrahydro cannabinaol on the behaviour of rats in open field arena. Psychopharmacol, 1980; 2:5-7.

Ozturk Y, Aydini S, Beis R, Baser KHC, Berberoglu H. Effect of Hypericum pericum L. and Hypericum calycinum L. extracts on the central nervous system in mice. Phytomed, 1996; 3(2):139-146.

Takagi K, Watanabe M, Saito H. Studies on the spontaneous movement of animals by the hole cross test: Effect of 2dimethylaminoethane Its acylates on the central nervous system. The Japanese J Pharmacol, 1972; 21(6):797-810.

Yu ZF, Kong LD, Chen Y. Antidepressant activity of aqueous extracts of Curcuma longa in mice. J Ethnopharmacol, 2002; 83(1-2):1615 .

How to cite this article:

Dasgupta T, Poddar SK, Ganguly A, Qais N. Anti-inflammatory and Neuropharmacological activities of the seed extract of Setaria italic. J App Pharm Sci, 2016; 6 (05): 193-197. 